\title{
Document Version Relationship Type Code
}

National Cancer Institute

\section{Source}

National Cancer Institute. Document Version Relationship Type Code. NCI Thesaurus.

Code C93818.

A coded value specifying the kind of document relationship. Each value implies specific constraints to what kinds of objects can be related and in which way. 